\title{
Relationship between Spot and Futures Markets of Selected Agricultural Commodities in India: An Efficiency and Causation Analysis
}

Raghavendra $\mathrm{RH}^{\star}$, Velmurugan PS and Saravanan A

Department of Commerce, School of Management, Pondicherry University (A Central University), Pondicherry, 605014 , India

\begin{abstract}
This study empirically examines the market which reacts first in India by assessing the relationship between spot and future prices of agricultural commodities such as Soya bean, Chana, Maize, Jeera and Turmeric for a period from January 2010 to March 2015 traded in NCDEX, Empirical results suggest the existence of long-run equilibrium relationships between futures and spot prices for all the 5 agricultural commodities that were taken for this study. Regression model pertaining to Lead-Lag relationship between Spot and Future markets suggests that for the commodities Maize, Jeera and Turmeric, both the spot and future markets price plays the leading role in the price discovery process and said to be informationally efficient and reacts more quickly to each other.
\end{abstract}

Keywords: Agriculture; Price discovery; Regression model; Futures; Cointegration

\section{Introduction}

The agricultural production system in India has undergone profound changes over the decades due to adoption of green revolution technologies coupled with price support policy of the government [1]. After independence, various policy initiatives undertaken for protecting agriculture sector affected the growth in agricultural commodities markets adversely. The Essential Commodities Act 1955 envisaged price and movement protection applicable to various agricultural commodities, particularly food grains such as paddy, wheat, coarse grains and pulses to protect the interests of producers as well as of consumers. During the process of economic liberalization, it was felt that there is a need to reorient policies and regulations in agricultural commodities. The Khusro Committee recommended reintroduction of futures trading in most of the major commodities [2]. The Government of India constituted another committee headed by Professor K.N. Kabra in June 1993 on Forward Markets [3], which also emphasized the need for introduction of futures trading in 17 commodity groups covering a wide range of agricultural commodities. It also recommended strengthening of the Forward Markets Commission (FMC) and various amendments in Forward Contracts (Regulation) Act 1952 to bring fairness and efficiency in futures trading operations.

The National Agriculture Policy announced in July 2000 envisaged external and domestic market reforms by putting in place a mechanism of futures trade/market and dismantling of all control and regulations in agricultural commodity market [4]. As a result, the Government of India issued notifications on April 1,2003 and permitted futures trading (except options trading) for a wide range of agricultural commodities.

Distress sale of agricultural commodities immediately after harvesting due to lack of farmers' capacity to wait for opportune time for getting remunerative prices and also because of the uncertainty involved in possible future prices has always been one of the major concerns for producers as well as consumers [4-6]. Futures contracts help in performing two important management functions, i.e. price discovery and price risk management for the specific commodity $[4,7,8]$. Price discovery is the process of revealing information about future spot prices through the future markets. It is useful for producers as they get a fair idea about the prices likely to prevail at a future point of time and hence, can allocate their limited available resources among various competing commodities for optimizing their profits. It also provides food processors and consumers an idea about prices at which the specific commodity would be available at a future point of time. Although futures trading in a large number of agricultural commodities were re-introduced in India in the year 2003, government is always skeptical about its efficiency and likely impact on the price movement of agricultural commodities. The ban on futures trading of some major agricultural commodities in February 2007 makes it imperative to explore whether the futures market has really been able to achieve its above-stated objectives of price discovery and risk management or not. Thus, understanding the influence of one market on the other and role of each market segment in price discovery is the central question in market microstructure design and has become an increasingly important research issue among academicians, regulators and practitioners alike as it provides an idea about the market efficiency, volatility, hedging effectiveness and arbitrage opportunities, if any.

The essence of the price discovery function hinges on whether new information is reflected first in changes of future prices or changes of spot prices. Hence, there exists lead-lag relationship between spot and futures market by information dissemination. All the information available in the market place is immediately incorporated in the prices of assets in an efficient market. So, new information disseminating into the market should be reflected immediately in spot and futures prices simultaneously. This will lead to perfect positive contemporaneous co movement between the prices of those markets and there will be no systematic lagged response and therefore no arbitrage opportunity.

*Corresponding author: Raghavendra RH, Research Scholar, Department of Commerce, School of Management, Pondicherry University (A Central University), Pondicherry-605 014, India, Tel: 0413-2655179; E-mail: raghavpondiuni@gmail.com

Received October 15, 2015; Accepted December 29, 2015; Published January 12, 2016

Citation: Raghavendra RH, Velmurugan PS, Saravanan A (2016) Relationship between Spot and Futures Markets of Selected Agricultural Commodities in India: An Efficiency and Causation Analysis. J Bus Fin Aff 5: 160. doi:10.4172/21670234.1000160

Copyright: () 2015 Raghavendra RH, et al. This is an open-access article distributed under the terms of the Creative Commons Attribution License, which permits unrestricted use, distribution, and reproduction in any medium, provided the original author and source are credited. 
This prediction arises directly from the Cost of Carry (COC) model of future pricing which postulates that

$$
\mathrm{Ft}=\mathrm{S}_{\mathrm{t}} \mathrm{e}^{(\mathrm{r}-\mathrm{y})(\mathrm{T}-\mathrm{t})}
$$

where, Ft is the futures price of the commodity at time $t$, St is the spot price of the commodity at time $t, r$ is the interest rate foregone while carrying the underlying commodity, $y$ is the price fluctuation on the commodity and $\mathrm{T}-\mathrm{t}$ is the remaining life of the futures contract. Equation (1) is justified by a "no-arbitrage" assumption, since Ft $>$ Ste $(\mathrm{r}-\mathrm{y})(\mathrm{T}-\mathrm{t})$ would enable traders/ farmers to profit by selling futures and buying at spot, while Ste $(\mathrm{r}-\mathrm{y})(\mathrm{T}-\mathrm{t})>\mathrm{Ft}$ would allow profits by buying futures and short selling at spot. The assumptions that underlie these arguments are that future and spot markets are perfectly efficient, and that transaction costs are zero. This simple version of the model also assumes that the interest rate and addition to price are constant over the life of the futures contract, although in practice they will vary, as will $r-y$, the net cost of carry of the underlying commodity. Most importantly, in the real world, the existence of market frictions such as transaction costs, margin requirements, short-sale constraints, liquidity differences and non-synchronous trading effects may induce lead-lag relationship between the futures contract and its underlying spot market. In addition, if there are economic incentives for traders to use one market over the other, a price discovery process between the two markets is likely to happen [9]. This implies that futures and spot market prices are inter-related and can be traced under different market frictions through price discovery mechanism.

Accordingly, there exist diversified theoretical arguments pertaining to the causal relationship between spot and futures markets by information dissemination. The main arguments in favor of futures market leads spot market are mainly due to the advantages provided by the futures market includes higher liquidity, lower transaction costs, lower margins, ease leverage positions, rapid execution and greater flexibility for short positions. Such advantages attract larger informed farmers/ traders and make the futures market to react first when market- wide information or major stock-specific information arrives. Thus, the future prices lead the spot market prices. In addition, the low cost contingent strategies and high degree of leverage benefits in futures market attracts larger speculative traders from a spot market to a more regulated futures market segments, leading to reduction in informational asymmetries of the spot market through reducing the amount of noise trading, helping price discovery, improving the overall market depth, enhancing market efficiency, and increase market liquidity.

In such a situation, the spot market will react first when marketwide information or major stock- specific information arrives. Hence, spot market leads the futures market. Besides, there exists a bidirectional relationship between the futures and spot markets through price discovery process [10-14], where both the spot and future markets are said to be informationally efficient and reacts more quickly to each other. However, frictions in markets, in terms of transaction costs and information asymmetry, may lead to return and volatility spillovers between spot and futures markets. Besides being of academic interest, understanding information flow across markets is also important for hedgers for hedging and devising cross-market investment strategies. This paper analyzes the issue of price on futures and spot markets which is of interest to traders, financial economists and analysts. Although futures and spot markets react to the same information, the major question is which market reacts first in agricultural commodity markets in India by assessing the relationship between the spot and future prices of Soya bean, Chana, Maize, Jeera and Turmeric commodities traded in NCDEX for the period from January 2010 to March, 2015 (Table 1).

\section{Review of Literature}

This section outlines both theoretical as well as empirical literature related to analyzing the theoretical arguments on the major question that which market price reacts first whether (a) futures prices tend to influence spot prices or (b) spot prices tend to lead futures prices or (c) a bidirectional feedback relationship exists between spot and futures prices.

Jian Yang and David J Leatham examined the price discovery function for three U.S. wheat futures markets, the Chicago Board of

\begin{tabular}{|c|c|c|c|c|c|}
\hline Symbol & Soya bean & Turmeric & Jeera & Chana & Maize \\
\hline Description & SYBEANIDR & TMCFGRNZM & JEERAUNJHA & CHILLI & MAIZEKHRF \\
\hline Trading system & NCDEX Trading System & NCDEX Trading System & NCDEX Trading System & $\begin{array}{l}\text { NCDEX Trading } \\
\text { System }\end{array}$ & $\begin{array}{l}\text { NCDEX Trading } \\
\text { System }\end{array}$ \\
\hline Hours of Trading & $\begin{array}{l}\text { Mondays through Fridays : } 10: 00 \\
\text { AM to } 05: 00 \text { PM }\end{array}$ & $\begin{array}{l}\text { Mondays through Fridays : } \\
\text { 10:00 AM to } 05: 00 \text { PM } \\
\text { Saturdays : } 10.00 \text { AM to } 2.00 \mathrm{PM}\end{array}$ & $\begin{array}{l}\text { Mondays through Fridays } \\
: 10: 00 \text { AM to 05:00 PM }\end{array}$ & $\begin{array}{l}\text { Mondays through } \\
\text { Fridays : 10:00 AM } \\
\text { to 05:00 PM }\end{array}$ & $\begin{array}{l}\text { Mondays through } \\
\text { Fridays: } 10: 00 \text { a.m. to } \\
11.30 \text { p.m./ } 11.55 \text { p.m }\end{array}$ \\
\hline Trading unit & $10 \mathrm{MT}$ & $5 \mathrm{MT}$ & $3 \mathrm{MT}$ & $5 \mathrm{MT}$ & $10 \mathrm{MT}$ \\
\hline Quot/BaseVal & Rs per Quintal & Rs. Per Quintal & Rs per Quintal & Rs. Per Quintal & Rs. Per Quintal \\
\hline Tick size & Rs. 1/- & Rs. 2 & Rs 5 & Rs. 2 & Re. 1 \\
\hline Max order size & $500 \mathrm{MT}$ & $250 \mathrm{MT}$ & $150 \mathrm{MT}$ & $150 \mathrm{MT}$ & $500 \mathrm{MT}$ \\
\hline Delivery center & Indore & Nizamabad & Unjha & Khammam & Gulabbagh \\
\hline Initial margin & $5 \%$ & $5 \%$ & $5 \%$ & $5 \%$ & $5 \%$ \\
\hline Opening of contracts & $\begin{array}{l}\text { Trading in any contract month will } \\
\text { open on the 10th of the month. } \\
\text { If the } 10 \text { th day happens to be a } \\
\text { non-trading day, contracts would } \\
\text { open on the next trading day }\end{array}$ & $\begin{array}{l}\text { Trading in any contract month } \\
\text { will open on the } 1 \text { st day of the } \\
\text { month. If } 1 \text { st happens to be a } \\
\text { non-trading day, contracts would } \\
\text { open on the next trading day }\end{array}$ & -do- & -do- & -do- \\
\hline Final Settlement Price & $\begin{array}{l}\text { The Final Settlement Price (FSP) } \\
\text { shall be arrived at by taking the } \\
\text { simple average of the last polled } \\
\text { spot prices of the last three } \\
\text { trading days, }\end{array}$ & $\begin{array}{l}\text { The FSP shall be arrived at by } \\
\text { taking the simple average of the } \\
\text { last polled spot prices of the last } \\
\text { three trading days }\end{array}$ & -do- & -do- & -do- \\
\hline
\end{tabular}

Source: Contract specification, NCDEX, India

Table 1: Future contract specifications of selected agricultural commodities traded in NCDEX 
Trade, Kansas City Board of Trade, and Minneapolis Grain Exchange. The maintained hypothesis is that futures markets search more for information than spot markets to find an equilibrium price, thus greatly improving the price discovery function. The tests reveal the existence of one equilibrium price across the three futures markets in the long run, but no cointegration among prices in the three represent active spot markets.

Silvapulle and Moosa investigated the relationship between futures and spot prices for the WTI crude oil, using daily observations during the period from 1985 to 1996 . Linear causality tests revealed that futures prices lead spot prices, while nonlinear causality tests showed that bidirectional causality between the two markets exists. In particular, they detected feedback from spot prices to futures prices and also that both the futures and the spot market react to new information at the same time. However, they indicated that this lead lag relationship varies significantly over different time periods. Summarizing, it should be pointed out that even if the futures market holds the dominant role to the price discovery procedure, the spot market plays an essential role for its function as well [15].

Fabio Mattos, Philip Garcia investigates the relationship between spot and futures prices in the Brazilian agricultural market, focusing on the effects of trading activity on the price discovery mechanism of futures markets. The results are mixed, but several points begin to emerge. In general, higher trading activity is linked to the presence of long-run equilibrium relationships between spot and futures prices. In these cases, futures prices appear to play a more dominant role in the pricing process. In more lightly traded markets, neither long run relationships nor short-run leads and lags can be found.

Kumar and Sunil investigated the price discovery in six Indian commodity exchanges for five commodities. For their study they have used the daily futures and spot price and also engaged the ratio of standard deviations of spot and future rates for empirical testing of ability of futures markets to incorporate information efficiently. Besides, the study has empirically analyzed the efficiency of spot and future markets by employing the Johansen cointegration technique. They found that inability of future market to fully incorporate information and confirmed inefficiency of future market. However, the authors concluded that the Indian agricultural commodities future markets are not yet mature and efficient [16].

Zapata, Fortenbery and Armstrong examined the relationship between 11 future prices traded in New York and the World spot prices for exported sugar by considering the observation from January 1990 to January 1995. They found that the future market for sugar leads the cash market in price discovery. However, they also found unidirectional causality from future price to spot but not vice versa. The finding of cointegration between futures and cash prices suggests that sugar future contract is a useful vehicle for reducing overall market price risk faced by spot market participants selling at the world price.

Kedarnath discussed the significance of price discovery and risk management by commodity futures for the development of commodity spot market in India. The result of interdependence between commodity future and spot market in agricultural commodities also supported the relevance of commodity future trading in Indian commodity market.

Jabir Ali, Kriti Bardhan Gupta analyzed the efficiency of agricultural commodity markets by assessing the relationships between futures prices and spot market prices of major agricultural commodities in India. The efficiency of the futures market for 12 agricultural commodities for the period of 2004 to 2007, traded at one of the largest commodity exchanges of India, i.e., National Commodity and Derivatives Exchange Ltd, has been explored by using Johansen's cointegration analysis and Granger causality tests. Unit root test procedures such as Augmented Dickey-Fuller and non-parametric Phillips-Perron were initially applied to examine whether futures and spot prices are stationary or not. Results show that cointegration exists significantly in futures and spot prices for all the selected agricultural commodities except for wheat and rice. This suggest that there is a long-term relationship between futures and spot prices for most of the agricultural commodities like maize, chickpea, black lentil, pepper, castor seed, soybean and sugar. The causality test further distinguishes and categorizes the commodities based on direction of relationship between futures and spot prices. The analysis of short-term relationship by causality test indicates that futures markets have stronger ability to predict subsequent spot prices for chickpea, castor seed, soybean and sugar as compared to maize, black lentil and pepper, where bidirectional relationships exist in the short run.

Given the above background, it should be pointed out that the above existing literatures pertaining to lead-lag relationship between price changes in international and domestic futures and spot markets are well established by information dissemination. They are related to different countries and consequently with different commodity market structure and macroeconomic fundamentals. Further, samples are drawn at different time periods and employed different models with different assumptions and obviously their results are mixed. Further, there is no specific study on these 5 agricultural commodities based on NCDEX data during the post global economic crisis period.

Hence based on the research gap, the present study attempts to investigate which market price reacts first between spot and futures prices of selected agricultural commodities traded in NCDEX, using $\mathrm{ADF}$ and PP test, Cointegration and Regression Model pertaining to Lead-Lag relationship between Spot and Future Markets.

\section{Data Source and Methodology}

\section{Data and tools used}

We used daily data of spot and future price of Soya bean, Chana, Maize, Jeera, and Turmeric for the period from January 2010 to March 2015 collected from National Commodity and Derivative Exchange (NCDEX). Rationale behind selecting these five agricultural commodities is that currently these five commodities' contracts are the most active trading contracts in NCDEX. In this study, the techniques used for analysis are panel unit root test which is Augmented DickeyFuller (ADF) test or Phillips-Perron (PP) test, Johansen Co-integration test and Regression Model pertaining to analyzing the Lead-Lag relationship between Spot and Future Markets.

Johansen's Cointegration and Regression model were employed to examine the lead-lag relationship between spot and futures markets of the selected agricultural commodities. Augmented Dickey-Fuller and Phillips-Perron tests were employed to verify the stationarity of the data series. Further, the necessary lag length of the data series was selected on the basis of Schwarz Information Criterion (SC). Johansen's Cointegration test is employed to examine long-run relationship among the variables after they are integrated in an identical order.

After identifying cointegration between spot and future prices of the selected agricultural commodities, the regression model was employed to examine the lead-lag relationship between the two and it is presented below: 


$$
\begin{aligned}
& \triangle S P O T_{t}=C_{1}+\sum_{k=1}^{n} \alpha_{1 i} \Delta S P O T_{t-k}+\sum_{k=1}^{n} \beta_{2 i} \Delta F U T_{t-k}+u_{1 t} \\
& \Delta F U T=C_{2}+\sum_{k=1}^{n} \beta_{1 i} \Delta F U T_{t-k}+\sum_{k=1}^{n} \alpha_{2 i} \Delta S P O T_{t-k}+u_{2 t}
\end{aligned}
$$

Where, SPOTt and FUTt are spot and future market prices of individual agricultural prices at time $t, \mathrm{u}_{1 \mathrm{t}}$ and $\mathrm{u}_{2 \mathrm{t}}$ are white noise disturbance terms. The analysis of unit root, co-integration and causality tests for different commodities were performed using econometric software Eviews Version 6.

\section{Results and Discussion}

Figures 1-5 plot the daily spot and future price movement of five Indian agricultural commodities viz., Soya bean, Chana, Maize, Jeera and Turmeric.

While observing the above graphs we can come to a conclusion that the futures price of agricultural commodity and the underlying spot market are moving into same direction. So there may be a chance to have an influence by the price of futures on the commodity spot market. In the coming part of the paper, examining the interrelation between spot and futures prices of selected agricultural commodities traded in NCDEX.

\section{Descriptive statistics}

Table 2 presents descriptive statistics for 5 spice agricultural commodities Chilli, Coriander, Jeera, Pepper and Turmeric traded in NCDEX India, from Januray 2010 - March 2015. The mean spot prices are Rs 3050.80, Rs. 3330.85, Rs. 1244.22, Rs. 13702.00 and Rs.7712.95 for Soya bean, Chana, Maize, Jeera and Turmeric respectively. Similarly, the mean futures prices are Rs.3020.63, Rs.3316.57, Rs.1226.92, Rs.13930.47 and Rs.7358.54 for Soya bean, Chana, Maize, Jeera and Turermic respectively.

The mean spot prices Soya bean, Chana, Maize and Turmeric are more than their mean future prices, except Jeera. Standard deviation, which is a tool for measuring volatility shows that the spot price of Soya bean, Chana and Turmeric are more volatile compared to their future prices. Whereas in the case of Jeera and Maize, the future prices are more volatile than the spot prices. Normality is tested using Jarque-
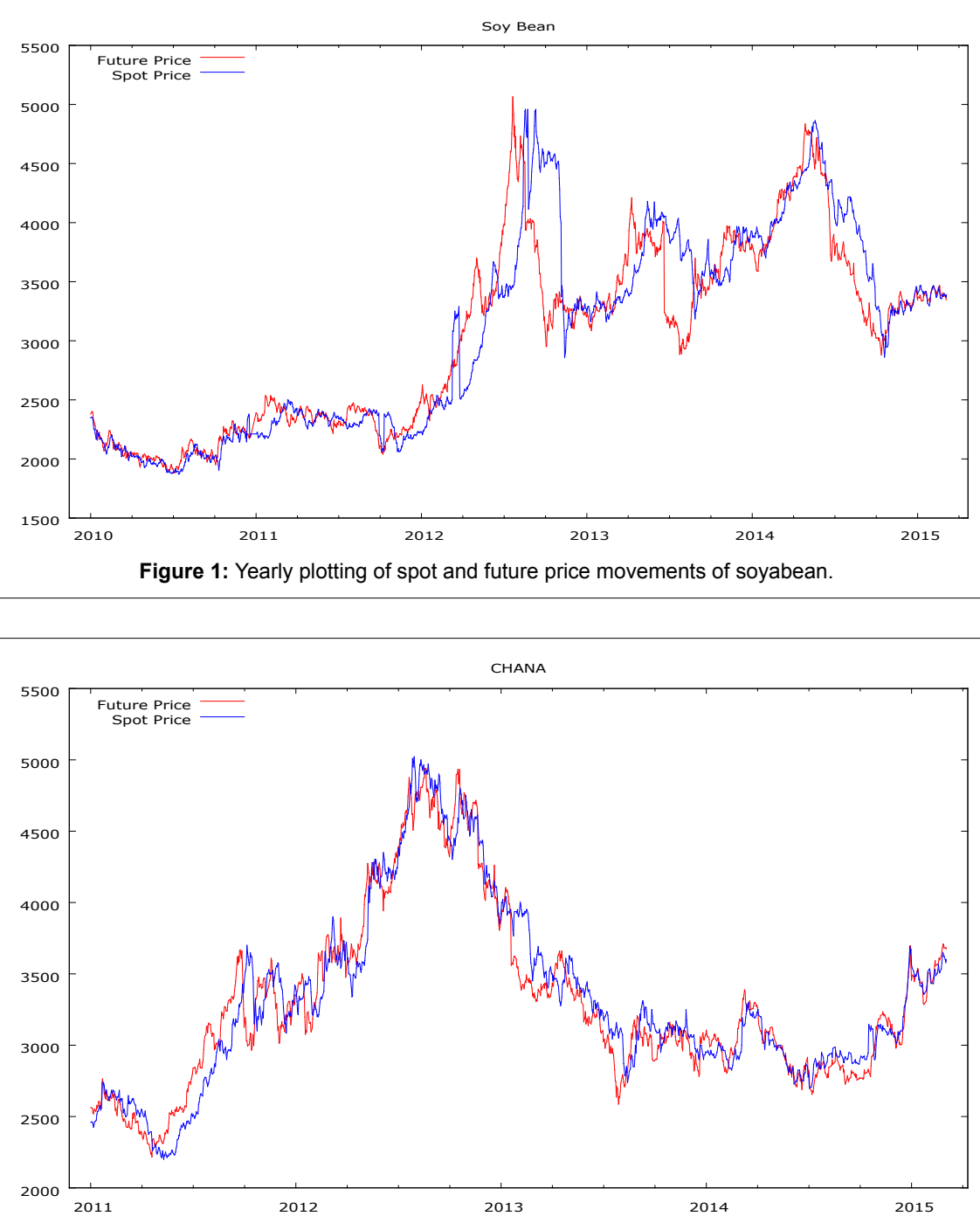

Figure 2: Yearly plotting of spot and future price movements of chana. 


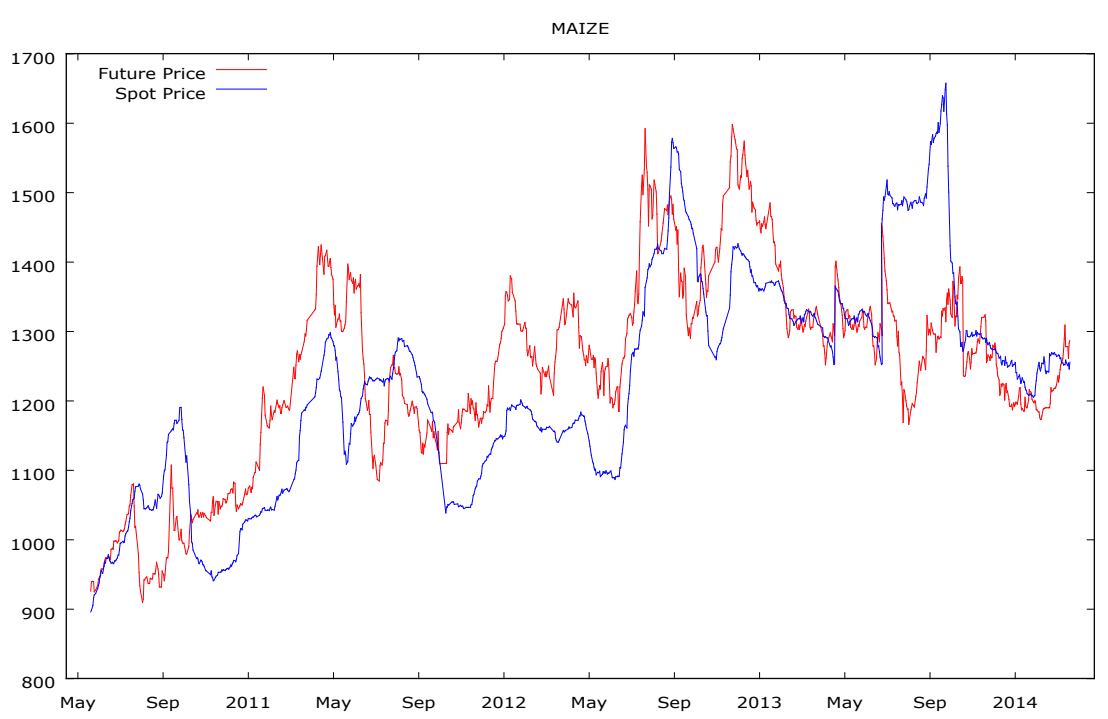

Figure 3: Yearly plotting of spot and future price movements of maize.

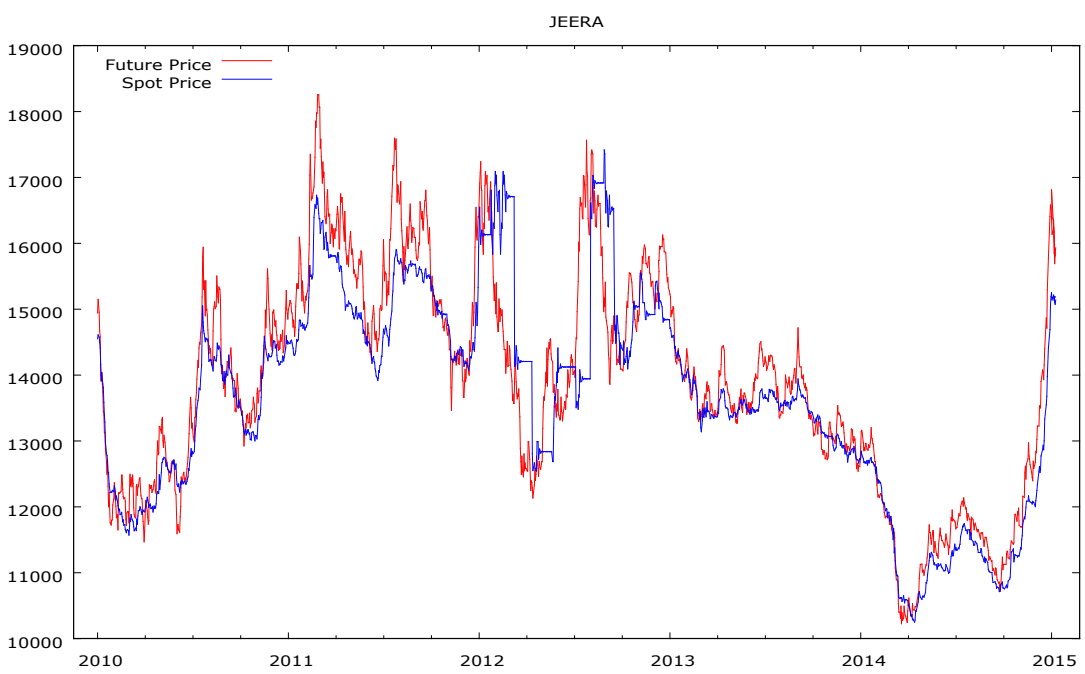

Figure 4: Yearly plotting of spot and future price movements of jeera.

\begin{tabular}{|c|c|c|c|c|c|c|c|}
\hline & & Mean & Std. Dev. & Skewness & Kurtosis & Jarque-Bera & Probability \\
\hline \multirow[t]{2}{*}{ Soy Bean } & Spot & 3050.8060 & 837.6233 & 0.2612 & 1.7829 & 111.9836 & 0.0000 \\
\hline & Future & 3020.6360 & 767.9924 & 0.2783 & 1.9711 & 87.3511 & 0.0000 \\
\hline \multirow[t]{2}{*}{ Chana } & Spot & 3330.8530 & 633.9555 & 0.7454 & 3.0603 & 114.5549 & 0.0000 \\
\hline & Future & 3316.5680 & 616.6130 & 0.8213 & 3.0841 & 139.2204 & 0.0000 \\
\hline \multirow[t]{2}{*}{ Maize } & Spot & 1244.2240 & 141.2040 & -0.2368 & 2.8247 & 10.9058 & 0.0043 \\
\hline & Future & 1226.9210 & 157.7985 & 0.1975 & 2.5725 & 14.4829 & 0.0007 \\
\hline \multirow[t]{2}{*}{ Jeera } & Spot & 13702.0100 & 1542.3830 & -0.0690 & 2.5067 & 16.5198 & 0.0003 \\
\hline & Future & 13930.4700 & 1634.3680 & 0.0305 & 2.4297 & 20.7128 & 0.0000 \\
\hline \multirow[t]{2}{*}{ Turmeric } & Spot & 7712.9580 & 3720.3760 & 1.1642 & 2.9688 & 337.7515 & 0.0000 \\
\hline & Future & 7358.5490 & 2718.7310 & 1.2149 & 3.7900 & 406.6315 & 0.0000 \\
\hline
\end{tabular}

Note: * $1 \%$ level significant

Sources: Calculated by the authors' using Eviews

Table 2: Descriptive statistics of different agricultural products.

Bera test, where it is found the data attained normality at $1 \%$ level. Kurtosis of the normal distribution is 3 for Chana spot and future and Turmeric futures. For all other commodities it is below 3. Finally, regarding the asymmetry of the distribution of the series around their 


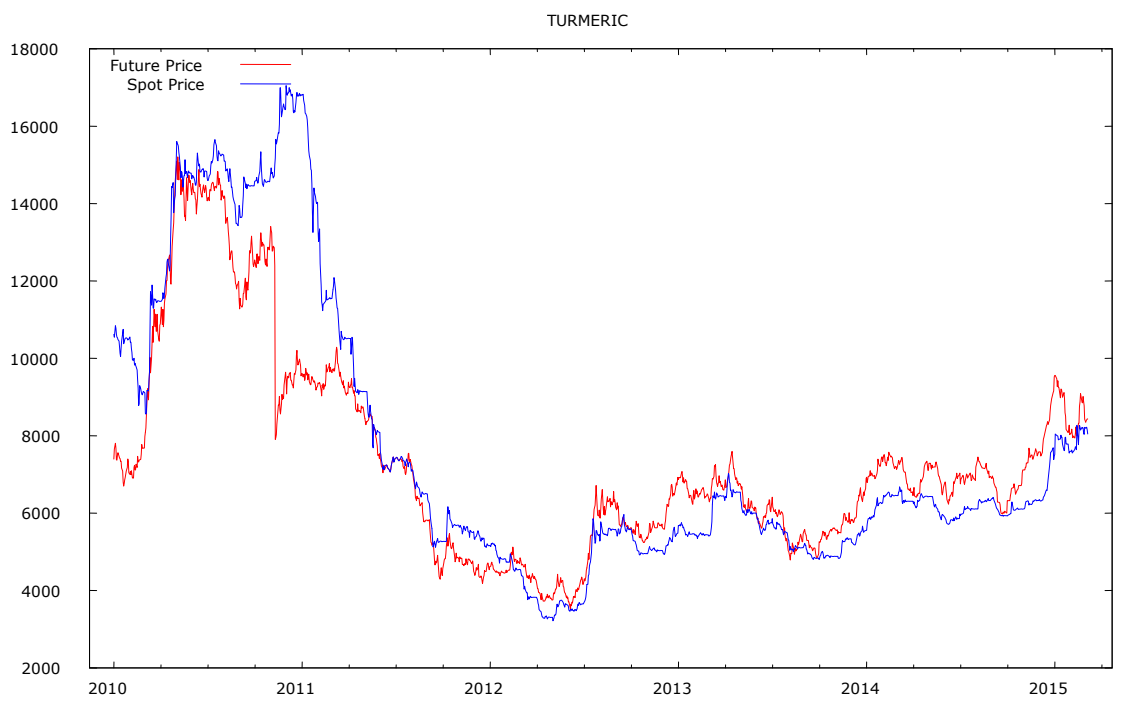

Figure 5: Yearly plotting of spot and future price movements of turmeric.

\begin{tabular}{|c|c|c|c|c|c|c|c|}
\hline & & \multicolumn{3}{|c|}{ ADF Test } & \multicolumn{3}{|c|}{ PP Test } \\
\hline & & Intercept & Intercept and Trend & No Intercept or Trend & Intercept & Intercept and Trend & No Intercept or Trend \\
\hline \multicolumn{8}{|l|}{ Panel A: Level } \\
\hline \multirow[t]{2}{*}{ Soy Bean } & Spot & -1.5361 & -2.3245 & 0.0071 & -1.5834 & -2.4034 & -0.0151 \\
\hline & Future & -1.6856 & -1.6711 & 0.0038 & -1.7309 & -1.7204 & -0.0412 \\
\hline \multirow[t]{2}{*}{ Chana } & Spot & 1.3042 & -1.2536 & 2.5519 & 1.2841 & -1.2692 & 2.5240 \\
\hline & Future & 0.1086 & -1.9616 & 1.4679 & 0.1351 & -1.9266 & 1.5171 \\
\hline \multirow[t]{2}{*}{ Maize } & Spot & -1.9639 & -1.8611 & -0.1262 & -2.3141 & -2.2742 & -0.1716 \\
\hline & Future & -2.3389 & -2.2527 & -0.1494 & -2.5774 & -2.5311 & -0.1757 \\
\hline \multirow[t]{2}{*}{ Jeera } & Spot & -1.5495 & -0.6471 & 1.1911 & -1.5125 & -0.9080 & 1.0570 \\
\hline & Future & -1.5911 & -1.2498 & 0.7440 & -1.5853 & -1.0966 & 0.8441 \\
\hline \multirow[t]{2}{*}{ Turmeric } & Spot & -1.0445 & -0.6875 & -0.8123 & -1.1253 & -0.8398 & -0.8272 \\
\hline & Future & -1.2428 & -1.1759 & -0.1910 & -1.3293 & -1.2957 & -0.2300 \\
\hline \multicolumn{8}{|c|}{ Panel B: First-difference } \\
\hline \multirow[t]{2}{*}{ Soy Bean } & Spot & $-26.3648^{*}$ & $-26.3540^{*}$ & $-26.3732^{*}$ & $-25.8837^{*}$ & $-25.8720^{*}$ & $-25.8949^{*}$ \\
\hline & Future & $-29.5034^{*}$ & $-29.4928^{*}$ & $-29.5102^{*}$ & $-29.7074^{*}$ & $-29.6967^{*}$ & $-29.7155^{*}$ \\
\hline \multirow[t]{2}{*}{ Chana } & Spot & $-37.4737^{*}$ & $-37.5825^{\star}$ & $-37.3700^{*}$ & $-37.4637^{*}$ & $-37.5625^{\star}$ & $-37.3873^{*}$ \\
\hline & Future & $-35.0390^{*}$ & $-35.0673^{*}$ & -34.9870 & -35.0200 & $-35.0787^{*}$ & -34.99621 \\
\hline \multirow[t]{2}{*}{ Maize } & Spot & $-37.5966^{*}$ & $-37.5943^{*}$ & $-37.6089^{*}$ & $-37.9334^{*}$ & $-37.9271^{*}$ & $-37.9447^{*}$ \\
\hline & Future & $-37.1192^{*}$ & $-37.1183^{*}$ & $-37.1313^{*}$ & $-37.1695^{*}$ & $-37.1670^{*}$ & $-37.1814^{*}$ \\
\hline \multirow[t]{2}{*}{ Jeera } & Spot & $-15.8670^{*}$ & $-15.9375^{\star}$ & $-15.7552^{*}$ & $-30.9909^{*}$ & $-30.8946^{*}$ & $-31.0035^{\star}$ \\
\hline & Future & $-28.1958^{*}$ & $-28.2217^{*}$ & $-28.1607^{*}$ & $-28.1945^{*}$ & $-28.2193^{*}$ & $-28.1607^{*}$ \\
\hline \multirow[t]{2}{*}{ Turmeric } & Spot & $-32.1049^{*}$ & $-32.1108^{*}$ & $-32.1115^{*}$ & $-32.6203^{*}$ & $-32.6107^{*}$ & $-32.6307^{*}$ \\
\hline & Future & $-36.3570^{*}$ & $-36.3511^{*}$ & $-36.3681^{*}$ & $-36.3504^{*}$ & $-36.3437^{*}$ & $-36.3617^{*}$ \\
\hline
\end{tabular}

${ }^{*} 1 \%$ and ${ }^{* *} 5 \%$ level significant

Sources: Calculated by the authors' using Eviews

Table 3: ADF test and PP test results.

mean, we found negative skewness for spot price of Maize and Jeera. For all other remaining price series is Soya bean, Chana and Turmeric there is positive skewness during the period of study.

\section{Unit root test}

In order to examine the cointegration of spot and futures prices of the selected commodity price series, it is customary to first examine the level of integration in each of the given commodity price series. This can be done by examining the unit root properties in each commodity price series. In this paper, we use the augmented Dickey-Fuller (ADF) test and the Phillips-Perron (PP) test to examine whether the sample commodity price series are stationary. Both tests are based on the null hypothesis that the series is unit root. Both tests are used without intercept and trend, with intercept and with intercept and trend. The ADF test assumes homogeneity in the disturbance term. However, the heterogeneity and temporary dependence in the disturbance term is accounted by the PP test.

Table 3 presents the results of ADF and PP tests for spot and future 
Citation: Raghavendra RH, Velmurugan PS, Saravanan A (2016) Relationship between Spot and Futures Markets of Selected Agricultural Commodities in India: An Efficiency and Causation Analysis. J Bus Fin Aff 5: 160. doi:10.4172/2167-0234.1000160

price of agricultural commodities Soya bean, Coriander, Jeera, Pepper and Turmeric traded in NCDEX India, from Januray 2010 - December 2015. Panel A in Table 3 presents the results of unit root tests in level series. Results show the non-rejection of the null hypothesis of the $\mathrm{ADF}$ and PP test for the selected agricultural commodity price series indicating that all the commodity price series under study are nonstationary series. Panel B in Table 3 reports the results of unit root tests in the first difference series. Results indicate that all commodity price series are I (1), that is, all the series become stationary after first difference. Hence, we can go forward to test the cointegration among them using Johansen cointegration test.

\section{Johansen co-integration test}

After testing the precondition of non-stationary time series (i.e. the series were stationary at their first difference) Johansen and Juselius cointegration test has been carried out to determine the existence of a long-run relationship between the selected agricultural commodities traded in NCDEX. Johansen Co-integration Test for agricultural commodities spot and future price in five groups was tested and displayed in Table 4 . The results show that all the above 5 group of selected agricultural commodities, there is evidence of co-integrating vector(s) according to the Trace statistic. That is between (a) Soya bean spot price and future price, (b) Chana spot price and future price (c) Maize spot price and future price (d) Jeera spot price and future price (e) Turmeric spot price and future price.

The co-integration results indicate that the $\mathrm{H}_{0}$ of zero can be rejected using the $95 \%$ critical value. This implies that the selected commodities spot and future prices are co-integrated with one cointegrating vector. The existence of cointegration between the spot and futures prices confirms the first necessary condition for long-term market relationship. Based on the cointegration test, we find that there is a long-market relationship in all the above 5 agricultural commodities traded in India (Soya bean, Chana, Maize, Jeera and Turmeric).

\section{Regression model for ascertaining lead-lag relationship}

The above Table 5 results of regression model reveal mixed findings. There is one-way causal linkage from future market to spot market prices for two agricultural commodities, viz., Soya bean and Chana. This indicates that information gets reflected first in the future prices and then it transmitted to spot market prices in the above two agricultural commodities. Further, the table result also confirms the

\begin{tabular}{|c|c|c|c|c|c|}
\hline Name of the Commodity & Ho: vector (r) & Trace statistic & $p$-value & Max-Eigen Statistics & p-value \\
\hline Soy Bean & $\begin{array}{l}r=0 \\
r \leq 1\end{array}$ & $\begin{array}{l}57.47021 \\
2.568548\end{array}$ & $\begin{array}{c}0.0000^{*} \\
0.1090\end{array}$ & $\begin{array}{l}54.90166 \\
2.568548\end{array}$ & $\begin{array}{c}0.0000^{*} \\
0.1090\end{array}$ \\
\hline Chana & $\begin{array}{l}r=0 \\
r \leq 1\end{array}$ & $\begin{array}{l}80.73057 \\
2.382425\end{array}$ & $\begin{array}{c}0.0000^{*} \\
0.1081\end{array}$ & $\begin{array}{l}81.73057 \\
2.582425\end{array}$ & $\begin{array}{c}0.0000^{*} \\
0.1081\end{array}$ \\
\hline Maize & $\begin{array}{l}r=0 \\
r \leq 1\end{array}$ & $\begin{array}{l}22.85695 \\
7.132841\end{array}$ & $\begin{array}{l}0.0033^{*} \\
0.0076^{*}\end{array}$ & $\begin{array}{l}15.72411 \\
7.132841\end{array}$ & $\begin{array}{c}0.0292^{* *} \\
0.0076^{*}\end{array}$ \\
\hline Jeera & $\begin{array}{l}r=0 \\
r \leq 1\end{array}$ & $\begin{array}{l}72.44795 \\
6.933486\end{array}$ & $\begin{array}{l}0.0000^{*} \\
0.0085^{*}\end{array}$ & $\begin{array}{l}65.51446 \\
6.933486\end{array}$ & $\begin{array}{l}0.0000^{*} \\
0.0085^{*}\end{array}$ \\
\hline Turmeric & $\begin{array}{l}r=0 \\
r \leq 1\end{array}$ & $\begin{array}{l}20.39199 \\
1.082463\end{array}$ & $\begin{array}{c}0.0084^{*} \\
0.2981\end{array}$ & $\begin{array}{l}19.30953 \\
1.082463\end{array}$ & $\begin{array}{c}0.0073^{*} \\
0.2981\end{array}$ \\
\hline
\end{tabular}

* $1 \%$ and ${ }^{* *} 5 \%$ level significant

Sources: Calculated by the authors' using Eviews

Table 4: Johansen co-integration test results.

\begin{tabular}{|c|c|c|c|c|c|c|c|c|}
\hline & $\begin{array}{l}\text { Regression } \\
\text { Equation }\end{array}$ & C & $\Delta \mathbf{S P O T}_{\mathrm{t}-1}$ & $\Delta \mathrm{SPOT}_{\mathrm{t}-2}$ & $\Delta \mathbf{F U T}_{\mathrm{t}-1}$ & $\Delta \mathrm{FUT}_{\mathrm{t}-2}$ & $\begin{array}{c}\text { Log } \\
\text { Likelihood }\end{array}$ & Inference \\
\hline \multirow[t]{4}{*}{ Soy Bean } & \multirow[t]{2}{*}{$\Delta \mathrm{F}$ on $\Delta \mathbf{S}$} & 7.9441 & -0.0371 & 0.0314 & 1.0498 & -0.0465 & \multirow[t]{2}{*}{-8152.103} & \multirow[t]{4}{*}{$\mathrm{F} \rightarrow \mathrm{S}$} \\
\hline & & $(0.1279)$ & $(0.1329)$ & $(0.1959)$ & $(0.0000)^{*}$ & $(0.0240)^{\star *}$ & & \\
\hline & \multirow[t]{2}{*}{$\Delta \mathbf{S}$ on $\Delta \mathbf{F}$} & -6.0926 & 1.1228 & -0.1489 & 0.0725 & 0.0168 & \multirow[t]{2}{*}{-8189.723} & \\
\hline & & $(0.2545)$ & $(0.0000)^{*}$ & $(0.0000)^{*}$ & $(0.0035)^{*}$ & $(0.5279)$ & & \\
\hline \multirow[t]{4}{*}{ Chana } & \multirow[t]{2}{*}{$\Delta \mathbf{F}$ on $\Delta \mathbf{S}$} & 14.5649 & 0.0167 & -0.0127 & 1.0255 & -0.0337 & \multirow[t]{2}{*}{-6618.622} & \multirow[t]{4}{*}{$\mathrm{F} \rightarrow \mathrm{S}$} \\
\hline & & $(0.0747)$ & $(0.6195)$ & $(0.6964)$ & $(0.0000)^{\star}$ & $(0.2558)$ & & \\
\hline & \multirow[t]{2}{*}{$\Delta \mathbf{S}$ on $\Delta \mathbf{F}$} & -0.8166 & 1.0748 & -0.1386 & 0.0674 & -0.0029 & \multirow[t]{2}{*}{-6411.629} & \\
\hline & & $(0.9059)$ & $(0.0000)^{*}$ & $(0.0000)^{*}$ & $(0.0055)^{*}$ & $(0.9079)$ & & \\
\hline \multirow[t]{4}{*}{ Maize } & \multirow[t]{2}{*}{$\Delta \mathbf{F}$ on $\Delta \mathbf{S}$} & 13.3268 & -0.0259 & 0.0257 & 1.0226 & -0.0328 & \multirow[t]{2}{*}{-4394.794} & \multirow[t]{4}{*}{$\mathrm{F} \leftrightarrow \mathrm{S}$} \\
\hline & & $(0.0091)^{*}$ & $(0.5968)$ & $(0.5981)^{*}$ & $(0.0000)^{*}$ & $(0.3028)$ & & \\
\hline & \multirow[t]{2}{*}{$\Delta \mathbf{S}$ on $\Delta \mathbf{F}$} & 1.055101 & 1.1942 & -0.2063 & 7.91E-06 & 0.9625 & \multirow[t]{2}{*}{-3926.328} & \\
\hline & & $(0.7438)$ & $(0.0000)^{*}$ & $(0.0000)^{*}$ & $(0.9997)$ & $(0.0000)^{*}$ & & \\
\hline \multirow[t]{4}{*}{ Jeera } & \multirow[t]{2}{*}{$\Delta \mathbf{F}$ on $\Delta \mathbf{S}$} & 117.8588 & 0.1480 & -0.1449 & 1.0215 & -0.0330 & \multirow[t]{2}{*}{-10159.98} & \multirow[t]{4}{*}{$\mathrm{F} \leftrightarrow \mathrm{S}$} \\
\hline & & $(0.0134)^{\star *}$ & $(0.0000)^{*}$ & $(0.0000)^{*}$ & $(0.0000)^{\star}$ & $(0.2155)$ & & \\
\hline & \multirow[t]{2}{*}{$\Delta \mathbf{S}$ on $\Delta \mathbf{F}$} & 31.3169 & 0.9694 & -0.0174 & 0.0803 & -0.0353 & \multirow[t]{2}{*}{-9767.564} & \\
\hline & & $(0.3934)$ & $(0.0000)^{*}$ & $(0.4948)$ & $(0.0001)^{*}$ & $(0.0852)$ & & \\
\hline \multirow[t]{4}{*}{ Turmeric } & \multirow[t]{2}{*}{$\Delta \mathbf{F}$ on $\Delta \mathbf{S}$} & 24.0386 & 1.0055 & 0.0096 & 1.0589 & -0.0664 & \multirow[t]{2}{*}{-9928.237} & \multirow[t]{4}{*}{$\mathrm{F} \leftrightarrow \mathrm{S}$} \\
\hline & & $(0.0994)$ & $(0.0000)^{*}$ & $(0.7797)$ & $(0.0000)^{*}$ & $(0.0110)^{\star *}$ & & \\
\hline & \multirow[t]{2}{*}{$\Delta \mathbf{S}$ on $\Delta \mathbf{F}$} & -20.1513 & 1.1715 & -0.1801 & 0.0713 & 0.0077 & \multirow[t]{2}{*}{-9478.873} & \\
\hline & & $(0.0620)$ & $(0.0000)^{*}$ & $(0.0000)^{*}$ & $(0.0043)^{*}$ & $(0.6900)$ & & \\
\hline
\end{tabular}

Notes: Parenthesis shows t-statistics ${ }^{*} 1 \%$ and ${ }^{*} 5 \%$ level significant

Sources: Calculated by the authors' using Eviews

Table 5: Regression model. 
Citation: Raghavendra RH, Velmurugan PS, Saravanan A (2016) Relationship between Spot and Futures Markets of Selected Agricultural Commodities in India: An Efficiency and Causation Analysis. J Bus Fin Aff 5: 160. doi:10.4172/2167-0234.1000160

bidirectional relationship between commodity futures and spot market for three selected agricultural commodities viz., Maize, Jeera and Turmeric. This reveals that both the spot and future markets price of these three agricultural commodities plays the leading role in the price discovery process and said to be informationally efficient and reacts more quickly to each other.

\section{Conclusion}

The future markets of agricultural commodity depends on the transparency and efficiency of its functioning in terms of price risk management, price discovery, flexible contact specification, controlling unfair speculation, commodity delivery system, coverage, infrastructural support, etc. Empirically the study of this research examines the market which reacts first in agricultural commodity markets in India by assessing the relationship between the spot and future prices of Soya bean, Chana, Maize, Jeera and Turmeric traded in NCDEX, using Johansen's cointegration approach. Empirical results suggest the existence of long-run equilibrium relationships between futures and spot prices for 5 agricultural commodities viz., Soya bean, Chana, Maize, Jeera and Turmeric that were taken under this study. The relationship direction of future price and spot price are in general, where there is one-way causal linkage from future market to spot market prices for two agricultural commodities, viz., Soya bean and Chana. Further, the table result also confirms the presence of bidirectional relationship between commodity futures and spot market for three selected agricultural commodities viz., Maize, Jeera and Turmeric.

\section{References}

1. Chand $R$ (2003) Government intervention in food grain market in new context. Policy Paper 19, National Centre for Agricultural Economics and Policy Research (NCAP), New Delhi, India.

2. Khusro Committee (1980) Report of the Committee on Forward Markets, Ministry of Civil Supplies, Government of India, New Delhi, India.
3. Kabra KN (2007) Commodity futures in India. Economic and Political Weekly 42: 1163-1170.

4. Sahadevan KG (2002) The sagging agricultural commodity exchanges: Growth, constrains and revival of policy options. Economic and Political Weekly 37: 3153-3160.

5. Singh JP (2001) Strategy for effective agricultural marketing extension to meet the challenges in $21^{\text {st }}$ century. Manage Extension Research Review.

6. Acharya SS (2001) Domestic agricultural marketing policies, incentives and integration, in Acharya SS, Choudhri DP (edn.), Indian Agricultural Policy at the Crossroads, Rawat Publications, Jaipur, India.

7. Kolamkar DS (2003) Regulation and policy issues for commodity derivatives in India. In Thomas S (eds.), Derivatives Market in India, OUP, New Delhi, India.

8. Ahuja NL (2006) Commodity derivatives market in India: development regulation and futures prospects. International Research Journal of Finance and Economics 2: 153-162.

9. Zou L, Pinfold J (2001) Price functions between NZSE 10 index, index futures and TeNZ: A Co-integration approach and error correction model. Working Paper Series Department of commerce, Massey University, Auckland.

10. Turkington J, David W (1999) Price Discovery and Causality in the Australian Share Price Index Futures Market. Australian Journal of Management 24: 97-113.

11. Chris B, Alistar GR, Stuart R (2001) A trading strategy based on the lead-lag relationship between the spot index and futures contract for the FTSE 100 International Journal of Forecasting 17: 31-44.

12. Hyun-Jung R, Graham S (2004) The impact of stock index futures on the Korean stock market. Applied Financial Economics 14: 243-251.

13. Kenourgios D (2004) Price Discovery in the Athens Derivatives Exchange: Evidence for the FTSE/ASE-20 Futures Market. Economic and Business Review 6: 229-243.

14. Chang CC, Lee YH (2008) Asymmetric Causal Relationship between Spot and Futures in Taiwan. International Research Journal Finance and Economics 14 113-121.

15. Silvapulle P, Moosa I (1999) The relationship between the spot and futures prices: evidence from the crude oil market. Journal of Futures Markets 19: 175-193.

16. Kumar S, Sunil B (2004) Price Discovery and Market Efficiency: Evidence from Agricultural Futures Contract. J South Asian Management 11 